\title{
An Observatory for Life Courses: Populations, Countries, Institutions, and History
}

\section{Karl Ulrich Mayer}

To cite this article: Karl Ulrich Mayer (2015) An Observatory for Life Courses: Populations, Countries, Institutions, and History, Research in Human Development, 12:3-4, 196-201, DOI: 10.1080/15427609.2015.1068051

To link to this article: https://doi.org/10.1080/15427609.2015.1068051

\section{(c) 2015 The Author(s). Published with license by Taylor \& Francis Group, LLC}

\section{曲 Published online: 27 Aug 2015.}

Submit your article to this journal $₫$

Џلll Article views: 460

Q View related articles

View Crossmark data \lceil

Citing articles: 4 View citing articles $\pi$ 


\title{
An Observatory for Life Courses: Populations, Countries, Institutions, and History
}

\author{
Karl Ulrich Mayer \\ Max Planck Institute for Human Development
}

\begin{abstract}
The study of life courses has been fragmented into research on various transitions and life phases, specific life domains, specific countries and different historical periods. Moreover, research on life courses tended to be analytically and topically divided between a number of disciplines like demography, economics, sociology, and psychology. In recent years, however, longitudinal data has accumulated rapidly and therefore it is now or very soon possible to establish a comprehensive observatory for life courses. By this I mean a data base which would represent highly representative samples of (national) populations as a yearly series of birth cohorts followed through the whole life, for a good number of countries, across a fairly long historical period, covering trajectories in different life domains.
\end{abstract}

\section{INTRODUCTION}

In my life as a social scientist and researcher I pursued a number of innovative goals in the attainment of which we have made only partial progress so far. First I wanted to open up the study of social inequalities and social (intergenerational) mobility by focusing on the life course as one of the essential mechanisms by which we can understand how inequalities are generated, transmitted, and come into effect. Second, I wanted to open up the study of aging and human development by conceptualizing life courses as social structures sui generis, that is, interrelated institutionalized sequences of positions in various societal subdomains. As a consequence I wanted to foster an innovative and interdisciplinary field of research where the life course is not parceled of into different life phases (childhood, adolescence, youth, old age) and disciplines (economics for careers, demography for family and fertility, sociology, for social mobility and migration, psychology for development, etc.). Third, I wanted to understand long-term social changes with the help of collective biographies of (birth) cohorts and by embedding life courses into population processes. Fourth, I wanted to unravel how life course patterns differ systematically between societies, not least in regard to the role played by various forms and manifestation of the welfare state. And, fifth, I like many others wanted to understand by which kind of processes and mechanisms continuities and discontinuities unfold across the life course, not least in regard to counterintuitive, off-diagonal linkages (resilience and failure despite opportunities).

Address correspondence to Karl Ulrich Mayer, Max Planck Institute for Human Development, Lentzeallee 94, 14195 Berlin, Germany. E-mail: mayer@mpib-berlin.mpg.de

This is an Open Access article distributed under the terms of the Creative Commons Attribution License (http://creativecommons.org/licenses/by/4.0/), which permits unrestricted use, distribution, and reproduction in any medium provided the original work is properly cited. 
In sum, probably more than many of my highly respected colleagues in this field, I was interested in the structural, institutional and macro-sociological aspects of the life course.

How to combine this in one single wish for the study of human development? What I would like to see is a database that would represent full or highly representative samples of populations as a yearly series of birth cohorts followed through the whole life, for a good number of countries, across a fairly long historical period of history, covering trajectories in different life domains (family, education, training, work, social relations, social security status), for significant personality characteristics and competencies, as well as crucial biomarkers. This, among many other research opportunities, would allow researchers to decompose the variance of life trajectories into individual fixed effects, variations across the life course, variations between social classes of origin, variations between cohorts (historical periods), gender differences, and variations between countries, and of course the higher order interactions between these variances. In the following I develop and illustrate these ideas—not least with examples from the German Life History Study.

\section{THE LIFE COURSE AS A MECHANISM FOR THE ALLOCATION OF SOCIAL INEQUALITY}

Social inequalities unfold across the life course as a sequence and as a consequence of prebirth conditions, infant development, kindergarten time and preschool, school, occupational and careers, family formation, savings and capital accumulation and pension rights up to the conditions or contexts of old-age chronic illness and care. Primary agents are mothers and fathers, school quality and siblings, labor markets and employing firms, wives and children, as well as the welfare state. Health, moreover, is a (preceding) condition and an outcome with potentially strong side effects in other life domains. Inequalities reinforce each other across life domains and life phases. The big question is to which extent inequalities across the life course are cumulative or can be compensatory, whether the allocation of inequalities is an ever-changing lifetime process or can be thought of as a transition to a more-or-less stable social class or status. In the social mobility literature the idea of "counter mobility" is prominent according to which (upper) middle-class parents somehow manage to bring failing children back to their status level. Other studies cast some doubt on what Peter Blau and Otis Dudley Duncan in their 1962 study on the "American Occupational Structure" called the "middle class membrane" allowing (working class) children to climb up without letting middle class children fall through (Diewald et al., 2015). "Regression" theorizing has probably too often implied that in the area of inequalities in the life course good conditions lead to good outcomes and vice versa and has thus fostered an overly deterministic picture of both intergenerational and intragenerational continuity. Too little attention has been paid to those resilient who prevail despite bad starting conditions and those who fail despite seemingly favorable contexts of social origin. A likely cause for such mismatches between the educational level and social class of origin families and those of its offspring are family troubles (Schoon, 2006).

Especially Jim Heckman's (2006) work has opened a crucial debate about how early inequalities are "fixed" at least in the sense that later interventions become more costly and thus more unlikely. The idea that cognitive and noncognitive "fates" are more or less set even preschool seems worthwhile to be checked much more carefully to avoid defeatism. A blossoming literature has examined various "scarring effects" on later-life outcomes such as "scarring" effects 
of unemployment (Gangl, 2004; Ökcan, Mayer, \& Lüdicke, 2010), educational failure relative to parents (Diewald, Schulz, \& Baier, 2015), employment interruption of women due to family obligations (Aisenbrey, Evertsson, \& Grunow, 2009) or of divorce.

At any rate, my "just-one-wish" data set and design would allow to trace these interconnections more effectively than now. The coming of age of household panel data and the emerging mergers of transition to adulthood studies on the one hand and health and retirement longitudinal studies on the other hand make such research avenues ever more realistic.

\section{COHORT DIFFERENCES AS A TOOL TO STUDY SOCIAL CHANGE}

Chauvel and Schröder (2015) used data from the Luxemburg Income Study to compare disposable income across age, period 1985 to 2005 and cohorts born between 1920 and 1975 for West Germany, France, and the United States to answer the long-standing question whether certain cohorts have benefited from or were disadvantaged relative to the overall trends of income development. For all of these three countries the cohort trend is about twice as strong as the age trend. For Germany the cohorts born 1945 and 1950 have been relatively privileged whereas the cohorts born 1070 and 1975 deviate negatively. In the United States all cohorts appear to have benefitted equally from the overall trend (with small negative deviations for the cohorts born 1935 and 1960), whereas for France both the cohorts born between 1920 and 1930 and the recent cohorts born after 1960 are disadvantaged relative to the general trend of increase in disposable income.

Members of the team of the German Life History Study have for West Germany and, partly also for East Germany, analyzed inequalities and trends for cohorts born between 1919 and 1971 with regard to inequalities of educational and occupational opportunities, family formation, divorce, and the division of labor in couples (Mayer, 2015). Among else, they found some quite monotonic trends (Blossfeld, Blossfeld, \& Blossfeld, 2015), massive cohort specific disadvantages for the war and postwar cohorts, and complex interactions with the baby boomers of the 1940 and 1964 cohort (Hillmert \& Mayer, 2004; Mayer, 1998) as well long-standing and persisting differences between East and West Germany (Buhr \& Huinink, 2015; Mayer \& Schulze, 2013).

These examples illustrate the multifold relationship of life courses to history and social change. First of all, life courses unfold in historical time. The human life span of 70 to 122 years can cut across marked change between historical periods (Vaupel, 2010). The succession of birth cohorts is a major universal mechanism of the social metabolism. Birth cohorts and generations are agents and carriers of social change. The flow of persons through the sequence of positions within organizations and institutions acts at the same time as a means of social reproduction in the sense of maintenance and stability and as a mechanism of change. Furthermore, under special but not so infrequent circumstances birth cohorts can "freeze" specific contexts of given historical periods for their remaining life span. Thus adverse economic conditions at the time of labor market entry can affect throughout later working lives despite strongly improving economic development (Manzoni, Härkönen, \& Mayer, 2014). This is meant by Karl Mannheim's phrase of Gleichzeitigkeit des Ungleichzeitigen ("the contemporaneity of the uncontemporaneous," Mannheim, 1964, p. 512). At any historical point in time the various age groups share the common present, but each has its own particular past shaping the present condition. Moreover, the 
relative size of birth cohorts can in the context of neighboring larger or smaller cohorts be by itself a significant determinant of diminished or enlarged life chances. This is the case especially under modern conditions of structures of positions (size of school classes, number of training slots, or number of jobs) that tend to be numerically rather inflexible. Finally, nationally representative data on specific cohorts does not only allow us to trace the impact of historical conditions on life chances much better than time series of aggregate, cross-sectional population, for example, as in the case of German reunification (Diewald, Goedicke, \& Mayer, 2006; Mayer \& Schulze, 2009, 2013), it also allows a more finely graded mapping of social change itself (e.g., in analyzing trends of social mobility, see Hillmert, 2015; Mayer \& Aisenbrey, 2007).

What our "just-one-wish" - data set could provide among else is good evidence how variation in life courses is a mixture between individual (constant) characteristics, individual change over time, and historical change across birth cohorts. Using data from the German Life History Study comparing cohorts born between 1919 and 1921 Diewald et al. (2015) concluded that 75\% of variance in occupational status can be explained by "fixed" individual characteristics such as social background and education whereas $25 \%$ are due to changes across working lives. The high proportion of variance attributable to time-constant individual differences indicates for Germany a high level of continuity in occupational careers (see also Manzoni et al., 2014).

\section{(WELFARE) STATES AND THE LIFE COURSE}

Countries with apprenticeship systems instead of direct transitions from schooling to the labor market have lower rates of youth unemployment and juvenile delinquency. In Sweden divorce and family interruptions do not disadvantage women in their subsequent working life like in many other countries. Germany shows no disproportionally higher health costs in the last year before death in contrast to, for example, the United States. In the Netherlands the proportion of elderly people in old-age homes is comparatively very high (Mayer, 1997). East Germany has very high rates of nonmarital births. Although in Germany highly educated couples have to a higher extent fewer or no children than less educated couples the opposite is true in the Scandinavian and Anglo-Saxon countries (Mayer, 2004). Sweden does not reduce the risk of job loss but minimizes its consequences. In Germany it tends be the other way around, and the United States neither reduces risks nor compensates their consequences (DiPrete, 2002). Life expectancy for males in Russia is almost 20 years lower than in the most developed countries.

These are all examples for how life courses vary quite systematically between countries (Mayer, 1997, 2001, 2004). These differences are due to historically developed differences in institutions (like in the degree of stratification of schooling or vocational education and training [VET] system), in the relative strength of collective actors like trade unions or differing incentive systems built into provisions of social assistance and social insurances, or in the relative strength of the private versus the public sector. My "just-one-wish" data and research design would allow to not only test whether the notion of cross-national variation in "life course regimes" can be upheld, but also how institutional change (e.g., in child care provision or early retirement regulations) affect life course outcomes. The breathtaking progress in this area is demonstrated by a new article by Van Winkle and Fasang (2015). Based on the SHARE data (the Health and Retirement Study for Europe) they are comparing working lives between age 10 and age 65 across 14 countries and a historical time span of 85 years. They dramatically concluded that social change is 
minute in comparison with the relative size of country differences. Only $1.5 \%$ of the variance in employment and job shifts is due to cohort differences, whereas $14 \%$ is due to differences between countries and about $75 \%$ due to between-person differences. Compositional effects due to person-related attributes like education, family status, gender, and so on plus type of welfare state reduce the total of country differences by $65 \%$, cohort differences by $18 \%$ (38\% for men and 5\% for women) and the overall variance by 12\% (Van Winkle \& Fasang, 2015, p. 31).

\section{THE PROSPECT FOR MY “JUST-ONE-WISH” DATA AND RESEARCH DESIGN}

How realistic is this plan for a population $\times$ aging $\times$ birth cohort $\times$ life domain $\times$ country data set and research design? One might argue that in times of heightened awareness of the protection of private data and of declining response rates in surveys the opportunities for putting this dream into reality might be farfetched. I do believe, however, that we are actually fairly close to its (partial) realization. This belief is based on several observations. First, prospective and retrospective longitudinal surveys have been ever more extended in their historical scope. The British cohort studies started in 1948 with four subsequent cohorts. The U.S. Panel of Income Study started in 1964 and the German Socio-Economic Panel in 1984. The German Life History Study covers the cohorts born between 1919 and 1971 and can be updated by the new German National Educational Panel (Blossfeld \& von Maurice, 2011). Second, we now do not only have an impressive set of national aging panel studies with some retrospective data like the Health and Retirement Study or the European SHARE study (see e.g., Van Winkle \& Fasang, 2015), but also panel studies on the earlier part in life are being extended into middle age, like in the National Educational Panel. Third, register data from administrative sources like in the Scandinavian countries have become more and more accessible and used in recent years. Finally, we could imagine a cognitive map in which results of existing studies that cover only parts of the data range could be fed in.

\section{REFERENCES}

Aisenbrey, S., Evertsson, M., \& Grunow, D. (2009). Is there a career penalty for mothers' time out? A comparison of Germany, Sweden and the United States. Social Forces, 88, 573-605. doi:10.1353/sof.0.0252

Blossfeld, H.-P., Roßbach, H.-G., \& von Maurice, J. (2011). Education as a Lifelong Process. The German National Educational Panel Study (NEPS). Zeitschrift für Erziehungswissenschaft, 14, special issue 14.

Blossfeld, P., Blossfeld, G., \& Blossfeld, H.-P. (2015). Universalization of upper secondary education, trends towards mass higher education and changes in inequality of educational opportunity in West and East Germany. European Sociological Review, 31(2), 144-160. doi:10.1093/esr/jcv017

Buhr, P., \& Huinink, J. (2015). Trends in family formation in East and West Germany: Past changes and Future expectations. European Sociological Review, 31(2), 197-210. doi:10.1093/esr/jcv013

Chauvel, L., \& Schröder, M. (2015). The impact of cohort membership on disposable incomes in West Germany, France and the U.S. European Sociological Review, advance online publication. doi:10.1093/esr/jcu091

Diewald, M., Goedicke, A., \& Mayer, K. U. (2006). After the fall of the wall. Life courses in the transformation of East Germany. Stanford, CA: Stanford University Press.

Diewald, M., Schulz, W., \& Baier, T. (2015). Intergenerational downward mobility in educational attainment and occupational careers in West Germany in the twentieth century. European Sociological Review, 31(2), 172-183. doi: $10.1093 /$ esr $/$ jcv010

DiPrete, T. (2002). Life course risks, mobility regimes, and mobility consequences. A comparison of Sweden, Germany, and the U.S. American Journal of Sociology, 103, 318-358. doi:10.1086/231210 
Gangl, M. (2004). Welfare states and scar effects of unemployment: A comparative analysis of the United States and West Germany. American Journal of Sociology, 92(1), 221-248.

Heckman, J. (2006). Skill formation and the economics of investing in disadvantaged children. Science, 312(5782), 1900-1902. doi:10.1126/science. 1128898

Hillmert, S. (2015). Changing structures of opportunity: A life-course perspective on social mobility and reproduction. European Sociological Review, 31(2), 184-196. doi:10.1093/esr/jcv012

Hillmert, S., \& Mayer, K. U. (2004). Geboren 1964 und 1971. Wiesbaden, Germany: VS Verlag für Sozialwissenschaften.

Mannheim, Karl (1964/1928). Das Problem der Generationen. In K. H. Wolff (Ed.), Wissenssoziologie. Auswahl aus dem Werk (p. 512). Berlin: Nwied.

Manzoni, A., Härkönen, J., \& Mayer, K. U. (2014). Moving on? A growth-curve-analysis of occupational career progression patterns in West Germany. Social Forces, 92, 1285-1312. doi:10.1093/sf/sou002

Mayer, K. U. (1997). Notes on a comparative political economy of life courses. In L. Mjoeset, F. Engelstad, G. Brochmann, R. Kalleberg, \& A. Leira (Eds.), Comparative social research (Vol. 16, pp. 203-226). Greenwich, CT: JAI Press.

Mayer, K. U. (1998). German survivors of World War II: The impact of the life course on the historical experiences of birth cohorts. In U. Gerhardt (Ed.), German sociology (pp. 207-221). New York, NY: The Continuum Publishing Company.

Mayer, K. U. (2004). Whose lives? How history, societies, and institutions define and shape life courses. Research in Human Development, 1, 161-187. doi:10.1207/s15427617rhd0103_3

Mayer, K. U. (2015). The paradox of global social change and national path dependencies. Life course patterns in advanced societies. In A. Woodward \& M. Kohli (Eds.), Inclusions and exclusions in European societies (pp. 89-110). London, England: Routledge.

Mayer, K. U. (Ed.). (2015). Social change, cohort inequalities and life courses in Germany since the 1920's Contributions from the German life history study. European Sociological Review, 31, 137-242

Mayer, K. U., \& Aisenbrey, S. (2007). Variations on a major theme - trends in social mobility in (West-) Germany for cohorts born between 1919 and 1971. In M. Gangl, R. Pollak, G. Otte, \& S. Scherer (Eds.), From origin to destination: Trends and mechanisms in social stratification research (pp. 125-154). Frankfurt, Germany: Campus Verlag.

Mayer, K. U., \& Schulze, E. (2009). Die Wendegeneration. Lebensverläufe des Jahrgangs 1971 [The Generation of Unification. Life Courses of the 1971 Birth Cohort]. Frankfurt am Main, Germany: Campus Verlag.

Mayer, K. U., \& Schulze, E. (2013). Delaying parenthood in East and West Germany. A mixed-methods study of the onset of childbirth and the vocabulary of motives of women of the birth cohort of 1971. In G. Neyer, G. Andersson, H. Kulu, L. Bernardi, \& C. Bühler (Eds.), The Demography of Europe (pp. 55-97). Dordrecht, The Netherlands: Springer.

Özcan, B., Mayer, K. U., \& Lüdicke, J. (2010). The impact of unemployment on the transition to parenthood. Demographic Research, 23, 807-846. doi:10.4054/DemRes.2010.23.29

Schoon, I. (2006). Risk and resilience: Adaptations to changing times. Cambridge, England: Cambridge University Press.

VanWinkle, Z., \& Fasang, A. (2015). Life course variation across time and space. Complexity in employment careers in Europe between 1924 and 2009. Paper presented at the 2015 Annual Meeting of the American Sociological Association, Humboldt-University, Berlin.

Vaupel, J. (2010). Biodemography of human ageing. Nature, 464, 536-542. doi:10.1038/nature08984 